
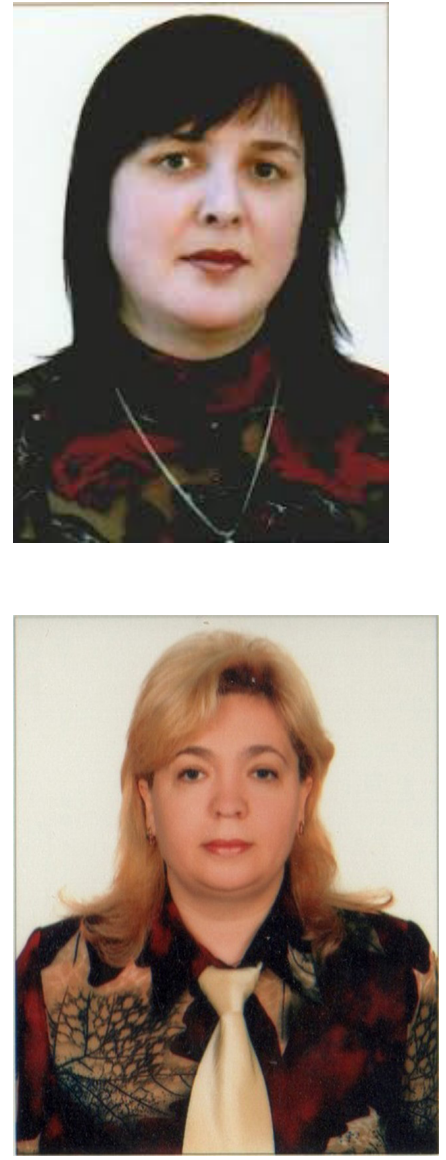

\section{Оксана Ворощук,}

кандидат педагогічних наук, доцент кафедри

соціальної педагогіки та соціальної роботи, ДВНЗ «Прикарпатський національний університет імені Василя Стефаника» (м. Івано-Франківськ, Україна)

\section{Oksana Vorochshuk,}

Candidate of Pedagogical Sciences, Associate Professor, Vasyl Stefanyk Precarpathian National University

(Ivano-Frankivsk, Ukraine)

oksanavorochshuk@gmail.com

ORCID 0000-0003-0835-544X

\section{Галина Лемко,}

кандидат педагогічних наук, доцент кафедри соціальної педагогіки та соціальної роботи, ДВНЗ «Прикарпатський національний університет імені Василя Стефаника» (м. Івано-Франківськ, Україна)

\section{Halyna Lemko,}

Candidate of Pedagogical Sciences, Associate Professor, Vasyl Stefanyk Precarpathian National University

(Ivano-Frankivsk, Ukraine)

halyna.lemko@gmail.com

ORCID 0000-0002-2922-8549

\title{
ПРОФЕСІЙНА ПІДГОТОВКА СОЦІАЛЬНИХ ПЕДАГОГІВ ДО ІНКЛЮЗИВНОГО НАВЧАННЯ ДІТЕЙ З ОСОБЛИВОСТЯМИ ПСИХОФІЗИЧНОГО РОЗВИТКУ
}

\footnotetext{
Анотація. Стаття присвячена питанню професійної підготовки соціальних педагогів до інклюзивного навчання
} дітей з особливими освітніми потребами в середовищі навчального закладу. Аналіз літературних джерел і власні наукові розвідки дають можливість розглянути компоненти професійної готовності майбутнього соціального педагога до роботи за умов інтеграції дітей з особливостями психофізичного розвитку. 3 метою формування у студентів професійної компетентності у сфері розвитку, навчання і виховання дітей з особливими потребами авторами складено схему підготовки фахівця до роботи на основі аналізу навчального плану зі спеціальності «Соціальна робота» (освітня програма «Соціальна педагогіка»). Виокремлено нормативні та вибіркові дисципліни циклу природничо-наукової і професійно-практичної підготовки, що забезпечують опанування студентами системою знань щодо анатомофізіологічних особливостей дітей з порушеннями в розвитку; перспективних напрямів, сучасних технологій соціальнопедагогічної роботи, методів корекційно-реабілітаційної роботи з дітьми, які мають особливості психофізичного розвитку; закономірностей міжособистісного спілкування тощо. Розглянуто емоційно-мотиваційний, когнітивний, діяльнісно-практичний критерії готовності майбутніх фахівців до інтеграції дітей з особливостями психофізичного розвитку в середовищі загальноосвітнього навчального закладу та їх змістові характеристики.

Ключові слова: інклюзія, інклюзивна освіта, соціальний педагог, діти з особливостями психофізичного розвитку, професійна підготовка.

\section{PREPARATION OF SOCIAL TEACHERS TO INCLUSIVE EDUCATION OF CHILDREN WITH THE SPECIAL NECESSITIES IN THE ENVIRONMENT OF GENERAL EDUCATIONAL INSTITUTIONS}

Abstract. The article is devoted to the question of professional preparation of social teachers to the inclusive studies of children with the special educational needs in the environment of general educational institutions. The analysis of literary sources and own scientific explore services gave an opportunity to consider the components of professional readiness of future social teacher to work in the conditions of integrationof children with features of psychophysical development. With 
the aim to form students' professional competence in the field of development, education and upbringing of children with special needs, by us was made the scheme for preparing a specialist to work on the basis of analysis of the curriculum in the specialty "Social work", educational program "Social pedagogy". Analyzing the plan, we have identified the normative and selective disciplines of the cycle of natural science and vocational training that providemasteringby students the system of knowledge about the anatomical and physiological features of children with developmental disabilities; perspective directions, modern technologies of social and pedagogical work, methods of correction and rehabilitation work with children who have features of psychophysical development; patterns of interpersonal communication, etc.

The emotional, motivational, cognitive and activity-practical criteria of the readiness of future social pedagogues to integrate children with features of psychophysical development in the environment of a comprehensive educational institution and their content characteristics are considered in the work. An important component of the educational process is pedagogical practice, which prepares future specialists for practical activity. In order to determine the state of teachers' readiness for work, we conducted a survey among

third year and fourthyearstudents. Inclusive education in Ukraine is developing, the legal framework is being improved, the specificity of the activities of social and pedagogical specialists in schools with inclusive orientation requires continuous self-improvement, wide awareness, knowledge, erudition, deep special knowledge and practical skills. training.

Keywords: inclusion, inclusive education, social pedagogue, children with features of psychophysical development, vocational

\section{ВСТУП}

Постановка проблеми. Сьогодні в Україні зростає увага до соціальних проблем, пов'язаних із захворюваністю серед дітей, які зумовлені неблагополучною еколого-економічною, соціально-психологічною ситуацією. Актуалізується проблема інтеграція дітей із особливими освітніми потребами. Першопричиною такого явища стало законне право дитини на якісне задоволення освітніх потреб. У закладах освіти зростає кількість дітей, які мають порушення психофізичного розвитку. Це спричиняє необхідність упровадження соціальної моделі підтримки, основою якої є взаємозв'язок, взаємодія дітей з суспільством. Реалізація цих завдань покладається на соціальних педагогів, психологів, соціальних працівників. Це спонукає виші до пошуку засобів удосконалення професійної підготовки майбутніх соціальних педагогів, зумовлює необхідність формування в них готовності до виконання специфічних завдань інклюзивної освіти, які реалізуються шляхом забезпечення повноцінного розвитку таких дітей.

Аналіз наукових досліджень і публікацій. Питання підготовки соціальних педагогів до професійної діяльності нині $€$ важливими й актуальними. Це засвідчують системні дослідження вітчизняних учених (В. Бондар, О. Васильченко, Р. Вайнола, Л. Дробот, В. Засенко, Т. Ілляшенко, А. Капська, А. Колупаєва, С. Литвиненко, Н. Мірошниченко, Г. Першко, В. Поліщук, Т. Сак, Т. Скрипник, Н. Стадненко, В. Тарасун, С. Харченко, М. Чайковський та ін.). Питання формування готовності майбутніх соціальних педагогів до різних видів соціально-педагогічної діяльності залишається актуальним.

\section{МЕТА І ЗАВДАННЯ ДОСЛІДЖЕННЯ}

Мета дослідження - здійснити аналіз професійної готовності соціальних педагогів до інклюзивного навчання дітей з особливостями психофізичного розвитку в загальноосвітній школі.

\section{РЕЗУЛЬТАТИ ДОСЛІДЖЕННЯ}

Нами складена схема підготовки фахівця на основі аналізу навчального плану зі спеціальності «Соціальна робота» (освітня програма «Соціальна педагогіка») освітньо-кваліфікаційного рівня «бакалавр» ДВНЗ «Прикарпатський національний університет імені Василя Стефаника» (табл.1).

Таблиця 1

\section{Схема підготовки соціальних педагогів до інклюзивного навчання} дітей з особливостями психофізичного розвитку

\begin{tabular}{|c|c|c|c|}
\hline $\begin{array}{c}\text { Рік } \\
\text { навчання }\end{array}$ & $\begin{array}{c}\text { Природничо-наукова } \\
\text { підготовка }\end{array}$ & Професійно-практична підготовка & Практична підготовка \\
\hline I курс & $\begin{array}{l}\text { Вікова фізіологія } \\
\text { Фізіологія ВНД } \\
\text { Вікова та педагогічна } \\
\text { психологія }\end{array}$ & $\begin{array}{l}\text { Соціальна педагогіка } \\
\text { Соціально-педагогічні основи розвитку } \\
\text { особистості } \\
\text { Соціальна молодіжна політика }\end{array}$ & $\begin{array}{l}\text { Навчально- } \\
\text { ознайомлювальна } \\
\text { практика в ЗОш }\end{array}$ \\
\hline II курс & $\begin{array}{l}\text { Основи дефектології } \\
\text { ОМЗ і психогігієна } \\
\text { Психодіагностика }\end{array}$ & $\begin{array}{l}\text { Етика соціально-педагогічної діяльності } \\
\text { Основи соціалізації особистості } \\
\text { Основи соціально-правового захисту } \\
\text { особистості } \\
\text { Соціальний супровід сім'ї } \\
\text { Технології соціально- педагогічної } \\
\text { діяльності }\end{array}$ & Волонтерська практика \\
\hline
\end{tabular}




\begin{tabular}{|c|c|c|c|}
\hline III курс & $\begin{array}{l}\text { Психологія особистості } \\
\text { Патопсихологія }\end{array}$ & $\begin{array}{l}\text { Соціально-педагогічний тренінг } \\
\text { Технології соціально-педагогічної } \\
\text { діяльності у сфері дозвілля } \\
\text { Соціально-педагогічні засади } \\
\text { міжособистісного спілкування } \\
\text { Самовиховання і саморегуляція } \\
\text { особистості } \\
\text { Основи профорієнтаційної соціально- } \\
\text { педагогічної діяльності }\end{array}$ & $\begin{array}{l}\text { Навчально-виховна } \\
\text { (літня) практика }\end{array}$ \\
\hline IV курс & Основи правознавства & $\begin{array}{l}\text { Основи соціально-психологічної терапії } \\
\text { сім'ї } \\
\text { Соціально-педагогічна діяльність } \\
\text { з дітьми і молоддю з особливими } \\
\text { потребами } \\
\text { Основи професійної майстерності } \\
\text { соціального педагога } \\
\text { Соціально-педагогічна діяльність за } \\
\text { місцем проживання } \\
\text { Соціально-педагогічна діяльність у } \\
\text { неповних сім'ях }\end{array}$ & $\begin{array}{l}\text { Виробнича практика в } \\
\text { ЗОш }\end{array}$ \\
\hline
\end{tabular}

Як бачимо з табл.1, навантаження на студентів поступово зростає і досягає свого максимуму на третьому курсі навчання. Нормативні та вибіркові дисципліни циклу природничо-наукової та професійно-практичної підготовки забезпечують опанування студентами системою знань щодо анатомо-фізіологічних особливостей дітей з порушеннями в розвитку; перспективних напрямів, сучасних технологій соціально-педагогічної роботи, методів корекційно-реабілітаційної роботи з дітьми, які мають особливі потреби; закономірностей міжособистісного спілкування; консультування тощо (Ворощук, 2016).

Засвоєння цих знань має забезпечити володіння вміннями: створювати сприятливі умови для стимулювання та активізації внутрішніх компенсаторних механізмів дітей з особливостями психофізичного розвитку; будувати навчально-виховний процес з урахуванням охоронно-оздоровчих, діагностичних і корекційно-реабілітаційних стратегій; активно використовувати та поєднувати різноманітні технології та форми допомоги; організовувати життєдіяльність з урахуванням потреб дітей; включати їх у систему широких соціально-педагогічних взаємин 3 однолітками з типовим розвитком та з дітьми інших вікових груп.

Зважаючи на те, що більшість дисциплін, які забезпечують професійно-практичну підготовку студентів спеціальності «Соціальна педагогіка», викладаються на третьому курсі, цільовою групою було обрано студентів, які пройшли повний цикл навчання на третьому курсі.

Для визначення стану готовності майбутніх соціальних педагогів до інклюзивного навчання дітей з особливими потребами ми взяли авторський діагностичний інструментарій О. Безпалько і Г.О. Першко (Першко, 2011). Учасниками стали студенти спеціальності «Соціальна педагогіка» Педагогічного факультету ДВНЗ «Прикарпатський національний університет імені Василя Стефаника». Базуючись на визначеннях готовності до педагогічної діяльності, виокремлено емоційно-мотиваційний, когнітивний та діяльнісно-практичний критерії готовності майбутніх соціальних педагогів до інтеграції дітей з особливостями психофізичного розвитку в середовищі загальноосвітнього навчального закладу та їх змістові характеристики.

Для визначення сформованості показників емоційно-мотиваційного критерію застосовано анкету. Мета анкетування полягала у визначенні ставлення студентів до майбутньої професійної діяльності 3 дітьми, які мають особливості психофізичного розвитку в інклюзивному середовищі навчального закладу. Відтак ми з'ясували, яке ставлення мають студенти до дітей з особливостями психофізичного розвитку. Отримані дані свідчать про те, що 25 \% студентів мають толерантне ставлення до дітей з особливостями психофізичного розвитку. Звісно, соціальний педагог має завжди поважати автономію дитини, бути вірним даному їй слову, надавати можливість висловлювати свої думки та почуття, заохочувати ї̈, підтримувати позитивну мотивацію, бути терплячим, якщо дитині необхідно пояснити чи показати щось багаторазово. До дітей з особливостями психофізичного розвитку 52,5\% студентів ставляться як до особливих. Це надзвичайно важливо, оскільки соціальний педагог має забезпечувати гідне ставлення до дитини, визначати домінантність її інтересів, уважно вислуховувати та надавати рекомендації, поради, а його поведінка має показувати повагу.

Здійснений аналіз уможливив визначити, що ніхто зі студентів не ставиться до дітей з особливостями психофізичного розвитку з почуттям відрази. Вірогідно, такі показники зумовлені недостатнім приділенням уваги моделюванню ситуацій, практичним вправам, бесідам, під час яких здійснюється роз'яснення студентам щодо того, що не можна ігнорувати дитину, припускатися зверхнього ставлення, допускати категоричні висновки, уживати терміни, які вказують на медичний діагноз, тощо.

Надзвичайно важливим для нас було визначити, які емоції переживають студенти, коли спостерігають за дітьми з особливостями психофізичного розвитку, адже таких дітей зазвичай сприймають по-різному.

За результатами анкетування, лише у 1,56\% студентів такі діти викликають симпатію, у 10,39\% - виникає зацікавленість до дітей з особливостями психофізичного розвитку. Варто зазначити, що студенти, які переживають 
вищезазначені емоції, можуть упевнено розвивати в них віру у себе, відкривати дітям радість спілкування, колективної праці, гри, відпочинку, виховувати в дітей благородне ставлення до тих осіб, які їх оточують. 19,97\% респондентів переживають хвилювання, 49,65\% - смуток, 14,45\% - збентеження, коли бачать дітей з порушеннями у розвитку.

Отож під час практичних занять для студентів необхідно проводити тренінги, у процесі яких основні зусилля спрямувати на поглиблення рефлексії, досягнення повної взаємоповаги, взаєморозуміння та довірливості між усіма учасниками групи, забезпечення саморозкриття та самоусвідомлення, що дасть змогу їм відчувати власну причетність до спільної справи. Також варто застосовувати інтерактивне навчання студентів, що сприятиме розвитку позитивних емоцій, створенню на заняттях відповідного емоційного мікроклімату, що сприятиме продуктивній спільній діяльності (симпатії, взаємодопомозі, загальній зацікавленості, доброзичливій обстановці, яка б знімала напругу тощо).

Незначна частина респондентів (4,24\%) визнала, що переживає страх. Цей факт спричинений відсутністю у студентів установки на професійне вдосконалення особистісних емоцій, що значною мірою перешкоджає успішності соціально-педагогічної роботи. Варто зазначити, що жоден зі студентів не переживаєте провини, коли бачить дитину з особливостями психофізичного розвитку. Ми вважаємо це позитивним моментом, оскільки ця емоція заважала б досягненню успіху в професійній діяльності майбутньому фахівцеві.

Під час дослідження важливо було з'ясувати, як почуваються студенти під час взаємодії 3 дитиною 3 особливостями психофізичного розвитку. Нами встановлено, що під час взаємодії з такою дитиною впевнено почувають себе 1,95\% студентів, комфортно - зі студентів не відчуває себе ніхто. Це не зовсім обнадійливі показники, що можна пояснити обмеженістю спілкування студентів з дітьми, які мають особливості психофізичного розвитку. Позитивним є те, що третина опитаних студентів $(30,42 \%)$ почувають себе спокійно. На жаль, чимало студентів (25,59\%) визнало, що почуваються напружено, 32,88\% студентів - нерішуче під час такої взаємодії. Експериментальні дані дають підстави стверджувати, що майбутні соціальні педагоги мають певні труднощі, коли будують стиль взаємин з дітьми, які мають особливості психофізичного розвитку.

Важливими є також дані щодо ставлення студентів до навчання дітей з особливостями психофізичного розвитку в загальноосвітній школі. Майже половина опитаних студентів $(27,54 \%)$ зазначила, що такі діти мають навчатися в загальноосвітніх навчальних закладах разом зі своїми однолітками. 37,68\% респондентів вважають, що такі діти мають навчатися у спеціальних загальноосвітніх навчальних закладах. Цей показник свідчить, що традиційно організований навчально-виховний процес вишу не створює достатніх сприятливих умов для формування готовності майбутніх соціальних педагогів до інклюзії. Орім того, 11,93\% студентів не змогли чітко визначитися в перевагах чи недоліках інклюзивного навчання. Це підтверджує необхідність активної роботи зі студентами щодо роз'яснення важливості та необхідності впровадження інклюзивного навчання та ролі соціального педагога в цьому процесі. Показовим, на нашу думку, є той факт, що жоден респондент не вважає, що такі діти мають здобувати освіту в домашніх умовах. Студенти розуміють, що діти з особливостями психофізичного розвитку мають навчатися в колективі здорових однолітків.

Нас також цікавили подальші професійні наміри студентів щодо діяльності з дітьми, які мають особливості психофізичного розвитку. За результатами анкетування, встановлено, що 5,76\% студентів готові працювати 3 такою категорією дітей, 29,98\% студентів - «скоріше так, аніж ні», тобто ці студенти розглядають можливість своєї професійної діяльності з дітьми зазначеної категорії та повною мірою усвідомлюють роль соціального педагога в інклюзивному середовищі школи, який має створювати в дитячому колективі атмосферу доброзичливості, взаємодопомоги, творчої співпраці, зацікавленості. Водночас варто зауважити, що 24,92\% студентам важко визначитися щодо своєї майбутньої професійної діяльності з такими дітьми.

Досить незначний відсоток опитаних (4,75\%) не планує працювати 3 означеною категорією дітей, а 24,92\% студентів теж схиляються до цього. Тобто майже третина опитаних не прагне до роботи з дітьми, які мають особливості психофізичного розвитку. Оскільки в опитуванні взяли участь студенти третього курсу, які ще не засвоїли всіх спеціальних дисциплін навчального плану та не оволоділи усіма видами практик, імовірно, що в майбутніх фахівців ще недостатньо сформовані уявлення про специфіку професійної діяльності соціального педагога в інклюзивному середовищі.

Для визначення сформованості показників когнітивного критерію готовності студентів до інклюзії нами було запропоновано тестове завдання. Варто зазначити, що ми не обмежували студентів кількістю обраних варіантів відповідей у кожному запитанні. Загалом тест містив 12 запитань. Умовно ми поділили запитання на чотири блоки.

Так, до чотирьох правильних відповідей тестового завдання зафіксовано у 6,10\% студентів. Ці студенти мають несистематичні знання, завдяки яким вони не зможуть керувати соціально-педагогічним процесом у школі, стимулювати дитину з особливостями психофізичного розвитку до саморозкриття і творчості, формувати у вихованців радість, доброзичливість, упевненість і оптимізм.

Від 4 до 8 правильних відповідей зафіксовано у 59, 41\% респондентів. Ці студенти мають посередні знання, які допоможуть здійснювати комплексний підхід до розв'язання проблем дитини з особливостями психофізичного розвитку, а саме: щодо навчання альтернативних способів спілкування; основних правил поведінки, прищеплювання навичок самообслуговування; розвитку зорового, слухового, тактильного сприйняття; виявлення та розвитку творчих здібностей дитини, проте ця група студентів повною мірою не зможе здійснити контроль за розвитком кожної дитини та створенням позитивного клімату навчально-виховного процесу закладу.

Відповідно кількість правильних відповідей від 8 до 12 нами зафіксовано у 34,49\% майбутніх фахівців. Ці студенти мають ґрунтовні знання, які загалом дають можливість розуміти причини психофізичних ускладнень дітей, незалежно від чинників, що зумовлюють їх виникнення; надавати допомогу та підтримку дітям у розв'язанні їх життєвих проблем, розв'язувати конфлікти між дітьми, з'ясовувати конкретні потреби дітей, мобілізувати їхні зусилля, здійснювати комплексне вивчення дітей тощо. 
Майбутні соціальні педагоги в процесі навчання мають оволодіти не лише теоретичними знаннями, а й необхідними вміннями та навичками, способами застосування набутих знань у практичній роботі.

Навчальна соціально-педагогічна практика є складником навчально-виховного процесу вищого навчального закладу. Тому формування показників діяльнісно-практичного критерію готовності майбутніх соціальних педагогів до інклюзії здійснювалися під час навчальної соціально-педагогічної практики студентів четвертого курсу спеціальності «Соціальна педагогіка» в загальноосвітніх навчальних закладах, де запроваджено інклюзивне навчання. Мета цієї практики - ознайомлення студентів з особливостями професійної діяльності соціального педагога в таких закладах, її значення полягало в розвитку професійних та особистісних якостей, які необхідні соціальним педагогам для роботи в середовищі загальноосвітнього навчального закладу, формуванні у студентів умінь та навичок, необхідних для роботи з дітьми, які мають особливості психофізичного розвитку.

Упродовж практики студенти мали змогу набути таких умінь та навичок: визначати соціальний статус дітей у класному колективі; здійснювати соціально-педагогічний супровід; надавати соціально-педагогічну підтримку дітям; налагоджувати взаємодію між учнями, батьками та педагогічними працівниками; організовувати роботу, спрямовану на реалізацію творчого потенціалу, здібностей і задатків дітей з особливостями розвитку.

Формування показників емоційно-мотиваційного критерію готовності майбутніх соціальних педагогів до інклюзії здійснювалося як під час аудиторних занять, так і в позааудиторній роботі зі студентами. За період роботи зі студентами проводилися фестивалі, благодійні акції, доброчинні проекти, кінофестивалі, відеолекторії, тематичні заходи, спрямовані на формування емпатійного ставлення до дітей з особливостями розвитку. Бажання працювати з дітьми, які мають особливості психофізичного розвитку, формувалося у студентів під час фестивалю «Повір у себе». Студенти-учасники, беручи участь у цьому заході, привітали дітей з особливостями психофізичного розвитку, а також спостерігали, як вони, виконуючи улюблені пісні, декламуючи вірші, беручи участь у постановці п'єс, діляться з тими, хто їх оточує, власними почуттями, думками, поглядами, мріями, сподіваннями. По завершенні фестивалю зі студентами було проведено обговорення їхньої участі у форматі інтенсивного обміну думками. Більшість студентів наголосили на значній необхідності проведення такого роду заходів. Варто зазначити, що майбутні фахівці не тільки передали дітям зібрані подарунки, а й підготували сувеніри, виготовлені власноруч. Такий знак уваги з боку студентів викликав жвавий інтерес у дітей, у результаті чого було проведено творчий майстер-клас, присвячений Великодню, і спільними зусиллями виготовлено оригінальні вироби. Працюючи з дітьми, студенти забезпечували їм соціальну, моральну, емоційну підтримку, набули досвіду успішної комунікативної діяльності, милосердя, співчуття в процесі взаємодії та піклування.

\section{ВИСНОВКИ ТА ПЕРСПЕКТИВИ ПОДАЛЬШИХ ДОСЛІДЖЕНЬ}

Отже, змістово-технологічне забезпечення професійної підготовки майбутніх соціальних педагогів до інклюзії здійснюється засобами комплексного поєднання теоретичної (навчальні курси «Соціально-педагогічна робота з дітьми і молоддю з особливими потребами», «Технології соціально-педагогічної діяльності») та практичної (організація соціально-педагогічної практики в ЗОШ) підготовки; різних форм позааудиторної роботи зі студентами (фестивалі, благодійні акції, доброчинні проекти, кінофестивалі, тематичні тижні, тематичні зустрічі). Перспективи подальших наукових розвідок полягають у розширенні інформаційного простору щодо професійної підготовки соціальних педагогів до інтеграції дітей з особливостями психофізичного розвитку в середовище навчального закладу, залучення фахівців і батьків до процесу навчання дітей і юнацтва 3 особливостями психофізичного розвитку тощо.

\section{СПИСОК ВИКОРИСТАНИХ ДЖЕРЕЛ}

Ворощук О. (2016). Підготовка соціальних педагогів до інклюзивного навчання дітей з особливими потребами у середовищі загальноосвітнього навчального закладу. Збірник наукових праць Кам'янець-Подільського національного університету імені Івана Огієнка / за ред. Л.П. Мельник, В.І. Співака. Вип. XXVII. Серія: соціально-педагогічна. Кам'янець-Подільський: ПП Медобори-2006, $61-71$

Першко Г. (2011). Підготовка соціальних педагогів до інтеграції дітей з особливостями психофізичного розвитку у середовище загальноосвітнього навчального закладу: автореф. на здобуття наук. ступеня доктора пед. наук : спец. 13.00.05 «Соціальна педагогіка». Київ.

\section{REFERENCES}

Voroshchuk, O. (2016). Pidhotovk sotsialnykh pedahohiv do inkliuzyvnoho navchannia ditei z osoblyvymy potrebamy u seredovyshchi zahalnoosvitnoho navchalnoho zakladu. Zbirnyk naukovykh prats Kamianets-Podilskoho natsionalnoho universytetu imeni Ivana Ohiienka. Issue XXVII. Seriia: sotsialno-pedahohichna. Kamianets-Podilskyi: PP Medobory-2006, 61 - 71

Pershko, H. (2011). Pidhotovka sotsialnykh pedahohiv do intehratsii ditei z osoblyvostiamy psykhofizychnoho rozvytku u seredovyshche zahalnoosvitnoho navchalnoho zakladu. (Extended Abstract of Candidate's thesis). Kyiv. 